Krzysztof BIERNAT

IEiB UKSW Warszawa

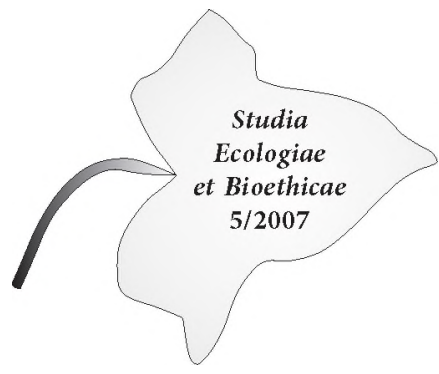

\title{
Biopaliwa drugiej generacji
}

\section{Wprowadzenie}

Zmiany konstrukcji silników spalinowych i urządzeń grzewczych powodowane głównie chęcią zwiększenia ich sprawności przy jednoczesnej poprawie ekonomiki eksploatacji, a także zaostrzające się wymagania z zakresu ochrony środowiska wymuszają również zmiany w asortymencie i jakości paliw do tych urządzeń. Paliwa, stanowiące źródła zasilania wszelkiego typu urządzeń powinny być traktowane jako istotny element konstrukcyjny, uwzględniany w fazie projektowania, i eksploatacyjny układu urządzenie-paliwo. Ze względu na swoje funkcje w takim układzie paliwo nie może być prawidłowo definiowane bez podania jego przeznaczenia, dopuszczalnego zakresu właściwości i sposobu ich oznaczania.

A zatem wszelkie substancje, które w efekcie procesów utleniania z wysokim efektem energetycznym mogą stanowić źródło energii, należy definiować jako materiały lub poprawniej substancje palne.

Substancje palne, w stosunku do których moźliwe jest technicznie przeprowadzenie procesu spalania w sposób kontrolowany oraz istnieją przesłanki umożliwiające wykorzystanie uzyskanej energii z tego procesu powinny być określane jako substancje (materialy) paliwowe. Kompozycja substancji paliwowych, o określonych właściwościach i metodach ich oznaczania, o przewidywanym zakresie zastosowań może być już uznawana jako paliwo niestandardowe. Z kolei paliwo niestandardowe może stać się paliwem standardowym czyli normatywnym, jeżeli na to paliwo zostanie ustanowiona norma przedmiotowa, zaakceptowana przez producentów silników lub urządzeń grzewczych, z jednoznacznym określeniem:

- zakresu (stosowania) normy;

- norm powołanych;

- sposobu pobierania próbek;

- oznakowania systemu dystrybucyjnego;

- ogólnych i szczegółowych wymagań oraz metod ich oznaczania;

- niezbędnych, dodatkowych danych dotyczących np.: specyficznych metod oznaczania niektórych wymagań, magazynowania, bezpieczeństwa bhp i ppoż. itp. 
Paliwa do silników spalinowych i urządzeń grzewczych muszą spełniać następujące wymagania, związane bezpośrednio lub pośrednio z zapewnieniem odpowiedniej sprawności, zużycia paliwa i ochrony środowiska oraz ogólnie racjonalności eksploatacji:

- wymagania zapewniające właściwy transport wewnętrzny paliwa (wymagania układu zasilania);

- wymagania zapewniające prawidłowe rozpylenie i odparowanie paliwa;

- wymagania zapewniające właściwe spalanie paliwa;

- wymagania związane z oddziaływaniem paliw i produktów ich spalania na środowisko;

- wymagania związane z magazynowaniem, transportem i dystrybucją paliw;

- wymagania związane ze sposobami postępowania z paliwami nie spełniającymi określonych norm przedmiotowych.

Rozwój i modyfikacje napędów współczesnych silników wymagają zatem odpowiednich paliw do tych napędów, tak aby spełnione zostały wymagania związane z podanymi powyżej wymaganiami. Wymagania te określają konstruktorzy i producenci pojazdów, gwarantując jednocześnie trwałość i niezawodność silników zasilanymi odpowiednimi dla niego paliwami.

Dla zapewnienia właściwej jakości paliw do silników o zapłonie iskrowym i samoczynnym, spełniające wymagania silników spalinowych i ochrony środowiska, czołowe, światowe koncerny samochodowe powołały Komitet do Spraw Światowej Karty Paliw (World-Wide Fuel Charter - WWFC). W skład Komitetu weszli jako członkowie przedstawiciele takich organizacji jak:

- ACEA (Association des Constructeurs Europeens d'Automobiles - Europejskie Zrzeszenie Producentów Samochodów);

- Alliance of Automobile Manufacturers (Stowarzyszenie Producentów Samochodów)

- EMA (Engine Manufactureres Association - Zrzeszenie Producentów Silników);

- JAMA (Japanese Automobile Manufactureres Association - Japońskie Zrzeszenie Producentów Samochodów).

Poza wymienionymi organizacjami w skład Komitetu weszli także przedstawiciele AIAM (Association of International Automobile Manufacturers - Międzynarodowego Zrzeszenia Producentów Samochodów) oraz następujących narodowych stowarzyszeń producentów samochodów i silników;

- kanadyjskiego zrzeszenia producentów samochodów (AIAMC) i zrzeszenia producentów pojazdów (CVMA);

- meksykańskiego zrzeszenia przemysłu motoryzacyjnego (AMIA);

- filipińskiej izby producentów samochodów (CAMPI);

- brazylijskiego zrzeszenia producentów silników i samobieżnych maszyn rolniczych (ANFAVEA);

- chińskiego zrzeszenia przemysłu motoryzacyjnego (CAAI); 
- koreańskiego zrzeszenia producentów samochodów (KAMA);

- południowo-afrykańskiego zrzeszenia przemysłu motoryzacyjnego (NAAMSA);

- tajskiego zrzeszenia przemysłu motoryzacyjnego (TAIA).

Organizacją wspierającą działania Komitetu jest także OICA (Organisation Internationale des Constructeurs d'Automobiles - Międzynarodowa Organizacja Konstruktorów Samochodów).

Aktualnie obowiązująca czwarta edycja Światowej Karty Paliw obowiązuje od września 2006r. Dzieli ona paliwa na cztery kategorie zarówno w grupie paliw do silników o zapłonie iskrowym jak i też samoczynnym.

W kategorii 1 zestawiono wymagania dla paliw stosowanych na rynkach bez zadnych, albo z minimalnymi wymaganiami, co do kontroli emisji szkodliwych składników spalin, spełniających głównie podstawowe wymagania silników i samochodów.

Kategoria 2 obejmuje paliwa użytkowane na rynkach o ostrzejszych wymaganiach ogólnych jak i tez z zakresu ochrony środowiska. W tej kategorii znajdują się paliwa spełniające wymagania US Tier 0 lub 1, EURO 1 i 2 lub równoważne wymagania z zakresu norm emisyjności toksycznych składników spalin.

W kategorii 3 mieszczą się paliwa przeznaczone na rynki o zaostrzonymi wymaganiami ogólnymi i z zakresu ograniczania emisji toksycznych składników spalin spełniające wymagania US California LEV, ULEV, EURO 3 i 4 lub równoważne wymagania co do emisyjności toksycznych składników spalin.

Ostatnia kategoria 4 obejmuje paliwa o najbardziej zaostrzonych wymaganiach jakościowych, szczególnie z zakresu emisji, łącznie z zaawansowanymi sposobami redukcji tlenków azotu i cząstek stałych ze spalin. Paliwa te muszą spełniać wymagania US California LEV-II, US EPA Tier 2, EURO 4 lub równoważne standardy tym wymaganiom, a także muszą być określone wymagania z zakresu ograniczania zużycia paliwa.

W stosunku do paliw spełniających wymagania Światowej Karty Paliw określają wymagania dla produktu gotowego. Jeżeli zatem paliwo spełnia te wymagania to nie należy określać i wprowadzać dodatkowych wymagań i metod kontroli pośredniej lub wewnętrznej.

Aktualne wymagania WWFC ograniczają wprowadzanie do benzyn związków tlenowych typu eterów lub etanolu i alkoholi wyższych, przy jednoczesnym zakazie wprowadzania do paliw metanolu. Dopuszczono maksymalną zawartość etanolu o wymaganiach zgodnych z ASTM D 4806 i pH zawartym w zakresie $6,5-9$ na $10 \%(\mathrm{v} / \mathrm{v})$, a alkoholi wyższych (od $\left.\mathrm{C}_{2}\right)$ nie więcej niż $0,1 \%(\mathrm{v} / \mathrm{v})$. Powyższe ograniczenia tłumaczone są pogorszeniem właściwości jezdnych i mało skutecznym zmniejszaniem emisji tlenków azotu w silnikach zasilanych mieszankami ubogimi. Stwierdzono także $w$ badaniach, że w procesie spalania benzyn z dodatkiem $10 \%$ etanolu, emisja toksycznych substancji obniżła się o $2 \%$, a emisja tlenku węgla o $10 \%$ w porównaniu z benzyną zawierającą 11\% MTBE, 
ale emisja tlenków azotu wzrosła o $14 \%$, węglowodorów o $10 \%$ oraz potencjał tworzenia ozonu o $9 \%$. A zatem przy wprowadzaniu do benzyn alkoholi nie zaleca się wprowadzania dodatkowo eterów. Zakaz wprowadzania metanolu wynika z możliwości spowodowania korozji części metalowych i degradacji komponentów plastycznych i elastomerów.

W olejach napędowych kategorii od pierwszej do trzeciej, WWFC ogranicza zawartość estrów pochodzenia roślinnego, głównie FAME (fatty acid methyl esters - estrów metylowych kwasów tłuszczowych), o wymaganiach jakościowych zgodnych z EN 14214, ASTM D 6751 lub normami równorzędnymi, do $5 \%$ $(\mathrm{v} / \mathrm{v}), \mathrm{z}$ powodu ich niekorzystnych właściwości niskotemperaturowych, higroskopijności, większej tendencji do tworzenia osadów i agresywnego oddziaływania na uszczelnienia i niektóre elementy układu paliwowego. Natomiast w olejach napędowych kategorii czwartej, zawartość FAME została ograniczona do granicy wykrywalności metody oznaczania. W przypadku wprowadzania FAME zalecane jest odpowiednie oznakowanie pomp paliwowych.

Ja wynika z powyższych danych, producenci silników są przeciwni niekontrolowanemu wprowadzaniu biopaliw do współczesnych silników spalinowych. Szczególne zagrożenia dla warunków eksploatacji, zdaniem producentów, wprowadzić mogą, dotychczas promowane alkohole i estry.

Stąd też biopaliwa stać się zatem dopiero mogą paliwami standardowymi o ile zabezpieczą w pełni wymagania silników i zostanie opracowana na nie norma przedmiotowa wraz z normami na metody badań.

Aktualnie pojęcie biopaliwa w Polsce sprowadza się jedynie do estrów metylowych wyższych kwasów tłuszczowych pochodzących z rzepaku i ich mieszanek $\mathrm{z}$ olejem napędowych potocznie, aczkolwiek niepoprawnie nazywanych „biodieslem" oraz alkoholu etylowego, zwanego „bioetanolem" wprowadzanego do benzyn silnikowych. Uznaje się także powszechnie i całkowicie błędnie, że biopaliwa nie emitują w procesie spalania ditlenku węgla $\left(\mathrm{CO}_{2}\right)$ do atmosfery. Oceniając zagrożenia dla środowiska jakie mogą wnieść biopaliwa należy uwzględniać emisyjność w całym procesie poczynając od uprawy, produkcji nawozów i nawożenia, eksploatacji maszyn i urządzeń rolniczych, transportu, procesów przeróbki, a kończąc na procesie spalania w silniku. Taki ciąg procesów określany jest jako „well to wheel", w skrócie WTW. Jednocześnie należy pamiętać, że węgiel jest podstawowym pierwiastkiem energetycznym występujących w związkach chemicznych zawartych w biopaliwach. Stąd też, uwzględniając emisję $\mathrm{CO}_{2}$ w cyklu WTW i porównując $\mathrm{z}$ ilością ditlenku węgla pochłoniętego przez rośliny stanowiące surowiec do produkcji biopaliw w procesie fotosyntezy, aktualnie stosowane biopaliwa wykazują bilans niekorzystny. W przypadku produkcji bioetanolu należy także uwzględniać duże ilości $\mathrm{CO}_{2}$ pochodzące z procesów fermentacji. Niezależnie od tego w cyklu WTW mogą być także wprowadzane do środowiska inne związki np. azotu i siarki, a wytwarzanie biopaliw z roślin uprawnych do celów spożywczych może zmniej- 
szyć ilość surowca przeznaczonego na te cele, a w konsekwencji doprowadzić do podwyższenia ceny żywności. Zagrożeniem dla środowiska może być także nadmierna eksploatacja zasobów leśnych, prowadząca nawet do całkowitej wycinki lasów i przeznaczania uzyskanych powierzchni na uprawy roślin energetycznych o zdecydowanie niższych zdolnościach asymilacji $\mathrm{CO}_{2}$.

\section{Podzial biopaliw}

Aktualnie w Europie biopaliwa definiowane są jako ciekłe i gazowe paliwa do silników spalinowych, otrzymywane z biomasy. Istnieje kilka wzajemnie uzupełniających się definicji biomasy. Zgodnie $z$ definicją europejską określoną w dyrektywie, biomasa stanowi biodegradowalne frakcje produktów, odpadów i pozostałości z przemysłu rolno-spożywczego ( $w$ tym substancje pochodzenia roślinnego i zwierzęcego), z leśnictwa i przemysłu pochodnego, a także biodegradowalne frakcje odpadów komunalnych i przemysłowych. Bardziej jednak racjonalną wydaje się być definicja określająca biomasę jako wszelkiego typu substancje, będące efektem naturalnych procesów biologicznych, w tym biochemicznych zachodzących w przyrodzie i stanowiące potencjalne źródła energii w ściśle określonych aplikacjach.

Podstawowym podziałem biopaliw jest ich podział ze względu na stan skupienia. Zgodnie z aneksem nr 1, Komunikatu Komisji Europejskiej nr 34 z 2006r, $\operatorname{COM}(2006) 34$ final, podzielono biopaliwa na ciekłe, gazowe oraz inne, wprowadzając po raz pierwszy w tym komunikacie pojęcia pierwszej i drugiej generacji biopaliw. Niezależnie od tego, zdefiniowano pojęcie „syntetyczne biopaliwa” określając je jako syntetyczne węglowodory lub ich mieszaniny otrzymywane z biomasy, np. SynGaz produkowany w procesach gazyfikacji biomasy leśnej lub SynDiesel.

W klasyfikacji europejskiej, ze względu na stan skupienia wydzielono następujące biopaliwa:

1) Biopaliwa ciekte:

- Bioetanol otrzymywany $\mathrm{z}$ biomasy i/lub z biodgradowalnych frakcji odpadowych, możliwy do zastosowania jako biopaliwo $\mathrm{E} \%$, zawierające 5\% etanolu i 95\% benzyny silnikowej oraz jako E85, zawierające $85 \%$ etanolu i 15\% benzyny;

- Biodiesel zawierający estry metylowe (PME, RME, FAME) otrzymane z olejów pochodzenia roślinnego i zwierzęcego lub odpadowych (np. posmażalniczych) tłuszczów i olejów, spełniające wymagania odpowiednich norm na oleje napędowe B5, zawierający 5\% estrów i 95\% naftowego oleju napędowego, B30, odpowiednio 30\% i 70\% oraz B100, stanowiący czyste estry o właściwościach zgodnych z odpowiednią normą;

- Biometanol jako paliwo lub komponent paliwowy otrzymywany z biomasy;

- Bio-ETBE, eter etylo tert-butylowy otrzymywany z bioetanolu, jako dodatek 
przeciwstukowy do benzyn podwyższający ich liczbę oktanową, stosowany wilości 47\%;

- Bio-MTBE, eter metylo tert-butylowy otrzymywany z biometanolu, o tym samym przeznaczeniu jak Bio-ETBE, stosowany w ilości 36\%;

- BtL, jako ciekłe frakcje i ich mieszaniny otrzymywane z biomasy, mogące stanowić biopaliwa lub komponenty paliwowe;

- czyste oleje roślinne, otrzymywane z procesów tłoczenia, ekstrakcji i podobnych procesów, łącznie z rafinacją, z wyłączeniem modyfikacji ich składu metodami chemicznymi, mogące stanowić biopaliwa spełniające wymogi ochrony środowiska, do odpowiednich typów silników.

2) Biopaliwa gazowe:

- Bio-DME, eter dimetylowy otrzymywany z biomasy do bezpośredniego stosowania jako biopaliwo do silników o zapłonie samoczynnym;

- Biogaz, jako biopaliwo otrzymywane z biomasy i/lub biodegradowalnych frakcji odpadowych, odpowiednio oczyszczony tak, aby odpowiadał jakością gazowi naturalnemu;

- Biowodór, jako biopaliwo otrzymywane z biomasy lub biodegradowalnych frakcji odpadowych.

3) Inne paliwa ze odnawialnych źródeł energii, jako nie wymienione powyżej biopaliwa, otrzymywane ze źródeł definiowanych Dyrektywą 2001/77/EC, które mogą być zastosowane do napędu w środkach transportu.

Jak już wspomniano, w tym samym komunikacie określono założenia podziału biopaliw na biopaliwa kategorii pierwszej oraz drugiej. Podział ten wynikał z omówionych powyżej uwarunkowań, a przede wszystkim z oceny przydatności paliw we współczesnej technice silnikowej i dostępności surowców oraz ich wpływu na środowisku. Formalny podział biopaliw na odpowiednie kategorie został opublikowany w raporcie „Biofuels in the European Vision, a Vision 2030 and Beyond". Raport ten dzieli biopaliwa na biopaliwa pierwszej generacji, tak zwane konwencjonalne oraz na biopaliwa drugiej generacji.

Do biopaliw pierwszej generacji (konwencjonalnych) zaliczone zostały:

- Bioetanol (BioEtOH) rozumiany jako konwencjonalny etanol otrzymywany z procesów hydrolizy i fermentacji z takich surowców jak: zboża, buraki cukrowe, itp.;

- czyste oleje roślinne (PVO-pure vegetable oils), otrzymywane z procesów tłoczenia na zimno i ekstrakcji ziaren roślin oleistych;

- Biodiesel stanowiący estry metylowe oleju rzepakowego (RME) lub estry metylowe (FAME) i etylowe (FAEE) wyższych kwasów tłuszczowych innych roślin oleistych otrzymywane w wyniku procesów tłoczenia na zimno, ekstrakcji i transestryfikacji;

- Biodiesel, stanowiący estry metylowe i etylowe otrzymywany w wyniku transestryfikacji posmażalniczych odpadów olejowych; 
- Biogaz, stanowiący oczyszczony biogaz z zawilgoconego biogazu składowiskowego, bądź rolniczego;

- Bio-ETBE, otrzymywany z przeróbki chemicznej bioetanolu.

Do biopaliw drugiej kategorii zostały sklasyfikowane:

- Bioetanol otrzymywany w wyniku zaawansowanych procesów hydrolizy i fermentacji lignocelulozy pochodzącej z biomasy ( $\mathrm{z}$ wyłączeniem surowców o przeznaczeniu spożywczym);

- syntetyczne biopaliwa stanowiące produkty przetwarzania biomasy poprzez zgazowanie i odpowiednią syntezę na ciekłe komponenty paliwowe (BtL), paliwa do silników o zapłonie samoczynnym pochodzące z przetwarzania lignocelulozy $z$ biomasy $w$ procesach Fischer-Tropscha, biodiesel syntetyczny z kompozycji produktów lignocelulozowych, biometanol, mieszaniny wyższych alkoholi oraz dimetyloeter (bio-DME);

- Bidiesel, jako biopaliwo lub komponent paliwowy do silników o zapłonie samoczynnym otrzymywany w wyniku rafinacji wodorem (hydrogenizacji) olejów roślinnych i tłuszczów zwierzęcych;

- Biogaz jako syntetycznie otrzymywany gaz ziemny (SNG), otrzymywany w wyniku procesów zgazowania lignocelulozy i odpowiedniej syntezy;

- Biowodór otrzymywany w wyniku zgazowania lignocelulozy i syntezy produktów zgazowania lub w wyniku procesów biochemicznych.

$Z$ powyższej klasyfikacji wynika, że nie można zaliczać do biopaliw drugiej generacji przetworzonych biopaliw pierwszej generacji, co oznacza, że dalsza przeróbka estrów, na przykład poprzez rafinację wodorem, nie powoduje otrzymania biopaliwa drugiej generacji i jest nieracjonalna technicznie i ekonomicznie. W zasadzie koncepcja rozwoju biopaliw drugiej generacji opiera się na założeniu, że surowcem do ich wytwarzania powinna być zarówno biomasa jak odpadowe oleje roślinne i tłuszcze zwierzęce oraz wszelkie odpadowe substancje pochodzenia organicznego, nieprzydatne w przemyśle spożywczym czy też leśnym.

Departament Transportu i Energetyki Komisji Europejskiej zaproponował wydzielenie biopaliw trzeciej generacji, jako tych, dla których opracowanie technologii powszechnego otrzymywania i wdrożenia ich do eksploatacji może być szacowane na lata 2030 i powyzej. Do tych paliw zakwalifikowano biowodór i bimetanol.

W USA nie występuje kategoryzacja biopaliw. Według opracowania NREL, (Narodowe Laboratorium Energii Odnawialnej) przewidywane jest stopniowe opracowywanie i wdrażanie technologii otrzymywania biopaliw w czasie.

Według danych NREL, aktualnie wdrażane są technologie następujących biopaliw:

- Etanolu jako komponentu biopaliwowego, którego surowcem stanowią ziarna zbóż oraz celuloza pochodząca z rolnictwa i leśnictwa;

- Biodiesel stanowiący mieszaninę estrów wyższych kwasów tłuszczowych z procesów tranestryfikacji olejów roślinnych i naftowego oleju napędowego; 
$\mathrm{W}$ perspektywie czasowej, przewidywane wdrażanie technologii kolejnych biopaliw:

- Green Diesel and Jet Fuel, tak zwany „zielony diesel” i uniwersalne paliwo do silników turbinowych (głównie jako paliwo dla potrzeb wojskowych), otrzymywane z tłuszczów, olejów odpadowych i czystych olejów roślinnych, rafinowanych w naftowych rafineriach do bardzo niskiego poziomu zawartości siarki;

- Inne produkty procesów fermentacyjnych biomasy, takie jak: butanol, octany (etaniany) i mleczany (2-hydroksy propaniany) i tym podobne;

- Ciecze popirolityczne, z procesów pirolizy biomasy jako alternatywny surowiec do rafinerii naftowych lub procesów zgazowania;

- Gaz syntezowy otrzymywany z biomasy metodą Fischer-Tropscha, jako surowiec do wytwarzania metanolu, eteru dimetylowego lub mieszanin alkoholi;

- Algae-derivated Fuels, paliwa pochodzące z biomasy z alg morskich, jako źródła triglicerydów do otrzymywania biodiesla, „zielonego diesla” i paliwa lotniczego Jet oraz jako surowce do otrzymywania węglowodanów;

- Paliwa węglowodorowe, jako biopaliwa dalekiej przyszłości, pochodzące z procesów biologicznych lub uwodornienia biomasy.

\section{Zastosowanie biopaliw}

Aktualny stan wiedzy i prowadzane badania w ośrodkach krajowych i zagranicznych, także w ramach Siódmego Programu Ramowego i Platform Technologicznych Biopaliw, polskiej i europejskiej doprowadziły do określenia obszarów zastosowań biopaliw w transporcie i energetyce. I tak jako biopaliwa i paliwa alternatywne dla silników o zapłonie iskrowym rozważane są:

- etanol;

- metanol;

- inne alkohole (np.: tert-butylowy - TBA, sec-butylowy - SBA, izopropylowy - IPA, neopentylowy - NPA);

- etery (etylo-tert-amylowy-TAEE, etylo-tert-butylowy-ETBE, metylo-tert-amylowy- TAME, metylo-tert-butylowy-MTBE, diizopropylowy-DIPE);

- węglowodorowe paliwa syntetyczne;

- skroplony gaz naftowy;

- wodór.

W zakresie zasilania silników o zapłonie samoczynnym, prowadzone są prace nad otrzymywaniem i stosowaniem następujących paliw alternatywnych pochodzących głównie z biomasy:

- estry kwasów thuszczowych, metylowe i etylowe, odpowiednio FAME i FAEE, z procesów transestryfikacji olejów: rzepakowego, słonecznikowego, sojowego itp;;

- eter dimetylowy (DME). Rozważany są także eter dietylowy (DEE); 
- emulsje paliwowo-wodne (Aquazole);

- czyste oleje roślinne;

- węglowodorowe paliwa syntetyczne.

W zastosowaniach stacjonarnych brane są pod rozwagę następujące paliwa:

- alkohole;

- estry wyższych kwasów tłuszczowych;

- paliwa talowe (TPO-tall pitch oils) otrzymywane w procesach estryfikacji alkoholami etylowym lub metylowym olejów talowych wydzielonych z żywicy drzew iglastych (produktów ubocznych, podczas produkcji celulozy siarczanowej oraz wytlewania drewna);

- paliwa z procesów pirolizy;

- czyste oleje roślinne;

- biogaz.

\section{Podstawowe technologie wytwarzania biopaliw drugiej generacji}

Ze względu na ochronę środowiska, dostępność i wymagania silników i urządzeń grzewczych, biopaliwa także, jako specyficzna grupa paliw „alternatywnych” powinna stanowić paliwa, które spełniają następujące warunki:

- występują w dostatecznie dużych ilościach;

- cechują się technicznymi i energetycznymi właściwościami determinującymi ich przydatność do zasilania silników lub urządzeń grzewczych;

- są tanie w produkcji i sprzedaży;

- stanowią mniejsze zagrożenia dla środowiska niż paliwa dotychczas stosowane;

- zapewniają możliwe do przyjęcia wskaźniki ekonomiczne silników lub kotłów i bezpieczeństwo ich użytkowania.

Oprócz tego biopaliwa powinny:

- zapewnić niezależność energetyczną;

- mieć mniejszą emisyjność związków toksycznych w procesie ich spalania;

- umożliwiać niższe koszty eksploatacji silników i urządzeń grzewczych.

Aktualne rozważane, zalecane do stosowania lub nawet stosowane biopaliwa, w chwili obecnej niestety nie spełniają w pełni powyższych warunków. Oceniając udział biopaliw w dotychczasowym i przyszłym rynku paliwowym należy dokonać oszacowania potencjału produkcyjnego paliw dla środków transportu pochodzenia roślinnego, $\mathrm{z}$ uwagi na możliwości surowcowe. Takie oszacowanie powinno również uwzględniać zaostrzające się wymagania środowiskowe. Bardzo ważne jest, że z punktu widzenia ograniczania emisji ditlenku węgla istotnym jest ograniczenie puli surowcowej do produkcji biopaliw do obszarów, nad którymi można sprawować kontrolę, tj. w praktyce do rolnictwa Wspólnoty, ponieważ w przeciwnym razie stosowanie biopaliw może doprowadzić do zwięk- 
szenia emisji $\mathrm{CO}_{2}$, gdzie już obecnie obserwuje się tendencję do wycinania lasów deszczowych aby powiększyć areał upraw roślin olejowych przeznaczonych na cele energetyczne. Takiego szacunku europejskiego potencjału surowcowego dla produkcji biopaliw dokonała Europejska Agencja ds. Środowiska. Koniecznym także jest wyeliminowanie z potencjalnej bazy surowcowej biopaliw takich surowców z rolnictwa, leśnictwa, eksploatacji zasobów wodnych, które mają istotne znaczenie w gospodarce żywnościowej.

Z powyższych względów, biopaliwa drugiej generacji mogą być wytwarzane w oparciu o odpadową biomasę, w tym także zawierającą organiczne frakcje odpadów komunalnych, odpadowe oleje roślinne i tłuszcze zwierzęce lub czyste oleje roślinne otrzymane $\mathrm{z}$ upraw na terenach zdegradowanych, nieprzydatne w przemyśle spożywczym.

Aktualne opracowywane lub wdrażane technologie z zakresu wytwarzania biopaliw drugiej generacji prowadzić mają do otrzymywania następujących paliw:

- alkoholu etylowego (BioEt) i estrów etylo-tert-butylowych (ETBE) z BioEt, otrzymywanych z biomasy lignocelulozowej z odpadów drzewnych, pozostałości z przemysłu młynarskiego i przetwórstwa zbóż oraz upraw buraków cukrowych i szybko rosnących roślin energetycznych;

- węglowodorowych paliw syntetycznych z procesów BTL („biomass to liquid"), otrzymywanych poprzez:

$>$ zgazowanie biomasy (tak zwanych „suchych odpadów” i z upraw szybko ro snących roślin energetycznych), a następnie syntezę Fischer-Tropscha (F-T) prowadzącą do otrzymania mieszaniny ciekłych węglowodorów jako paliwo „FT-diesel";

$>$ pirolizę biomasy, prowadzącą do otrzymania gazów (metanu, ditlenku węgla i pary wodnej), ciekłej frakcji zwanej bioolejem i pozostałości stałych zawierających węgiel drzewny i popiół. Bioolej, w procesie zgazowania i syntezy F-T , przerabiany jest na odpowiednie mieszaniny węglowodorowe, jako paliwo „FT-diesel”;

- paliwo HTU-diesel, pochodzące z procesów depolimeryzacji w wysokiej temperaturze („Hydro Thermal Upgrading”) i ewentualnego dalszego katalitycznego odtleniania, a dokładniej hydroodtleniania w procesie HDO (,hydrodeooxygenation"), biomasy, stanowiącej wszelkie pozostałości organiczne wraz z wysoką zawartością wody.

Technologia przeróbki materiałów lignocelulozowych na etanol polega na procesie enzymatycznej fermentacji włókien celulozowych. W procesie obróbki wstępnej, surowiec jest traktowany rozworami kwasów lub zasad wraz z przegrzaną parą wodną umożliwiając w efekcie właściwe przygotowanie polimerów ligniny i hemicelulozy do procesu hydrolizy, w którym to procesie następuje przekształcenie hemicelulozy na cukry $\mathrm{C}_{5}$, ksylozy i $\mathrm{C}_{6}$, glukozy, a następnie fermentacji tych cukrów do etanolu. Podstawowym problemem technologicznym 
jest doprowadzenie do jednoczesnej fermentacji glukozy i ksylozy, dobór odpowiednich enzymów oraz hodowla właściwych szczepów drożdży dla przeprowadzenia skutecznej fermentacji ksylozy.

Technologie otrzymywania paliw typu FT-diesel oparte są w zasadzie na procesie syntezy Fischer-Tropscha w jej różnych odmianach, w której surowcami są tlenek węgla i wodór, a produktami węglowodory alifatyczne i woda w myśl reakcji:

- prowadzonej w obecności katalizatora kobaltowego:

$\mathrm{CO}+2 \mathrm{H}_{2}=\left(-\mathrm{CH}_{2}-\right)+\mathrm{H}_{2} \mathrm{O}$

- prowadzonej z nadmiarem tlenku węgla w obecności katalizatora żelazowego: $2 \mathrm{CO}+2 \mathrm{H}_{2}=\left(-\mathrm{CH}_{2}-\right)+\mathrm{CO}_{2}$

W procesie zgazowania biomasy, w efekcie kilku etapów procesu, otrzymywany jest gaz syntezowy zawierający głównie tlenek węgla i wodór oraz w mniejszych ilościach ditlenek węgla, parę wodną, metan i wyższe węglowodory oraz azot. W chemizmie procesów zgazowania można wyróżnić następujące reakcje:

- utlenianie zupełne biomasy do ditlenku węgla (spalanie):

$\mathrm{C}+\mathrm{O}_{2}=\mathrm{CO}_{2} ; \Delta \mathrm{H}<0$

- częściowe utlenianie:

$\mathrm{C}+1 / 2 \mathrm{O}_{2}=\mathrm{CO} ; \Delta \mathrm{H}<0$

- reakcja Boudouarda:

$\mathrm{C}+\mathrm{CO}_{2}=2 \mathrm{CO} ; \Delta \mathrm{H}>0$

- reakcje gazu wodnego do tlenków węgla i wodoru:

$\mathrm{C}+\mathrm{H}_{2} \mathrm{O}=\mathrm{CO}+\mathrm{H}_{2} ; \Delta \mathrm{H}>0$

$\mathrm{C}+2 \mathrm{H}_{2} \mathrm{O}=\mathrm{CO}_{2}+\mathrm{H}_{2} ; \Delta \mathrm{H}>0$

- reforming z parą wodną (konwersja $\mathrm{CO}$ ):

$\mathrm{CO}+\mathrm{H}_{2} \mathrm{O}=\mathrm{CO}_{2}+\mathrm{H}_{2} ; \Delta \mathrm{H}<0$

- metanizacja węgla $\mathrm{z}$ biomasy:

$\mathrm{C}+2 \mathrm{H}_{2}=\mathrm{CH}_{4} ; \Delta \mathrm{H}<0$

- metanizacja tlenku węgla:

$\mathrm{CO}+3 \mathrm{H}_{2}=\mathrm{CH}_{4}+\mathrm{H}_{2} \mathrm{O} ; \Delta \mathrm{H}<0$

Ta ostatnia reakcja może być prowadzona w odwrotnym kierunku, jako proces reformingu parowego metanu. Jak widać, większość reakcji stanowią reakcje egzotermiczne $(\Delta \mathrm{H}<0)$, jednak konwersja węgla z parą wodną i reakcja Boudouarda mają charakter endotermiczny, stąd też proces zgazowania może być prowadzony przy bezpośrednim lub pośrednim dostarczaniu ciepła procesowego ponieważ te procesy zachodzą w temperaturze $(800-1000)^{\circ} \mathrm{C}$. Powstający w wyniku zgazowania bio-syngaz, po złożonym procesie oczyszczania i odpowiedniej segregacji, kierowany jest do syntezy F-T. Aktualnie koszty produkcji „FT- diesla" z instalacji doświadczalnej szacowane są na kwotę 1,30 €/l, gdy cena naftowego oleju napędowego wynosi $0,88 € / 1$.

Proces pirolizy biomasy prowadzony jest bez dostępu tlenu lub z częściowym utlenieniem, w temperaturze $(500-800)^{\circ} \mathrm{C}$, często w obecności katalizatorów. 
W efekcie tego procesu, bezpośrednio lub ze stopionej biomasy otrzymywane są mieszaniny oligomerów i monomerów stanowiące olej popirolityczny, tak zwany bioolej oraz frakcja gazowa zawierająca metan, ditlenek węgla i parę wodną. Stałą pozostałość procesową stanowi „charcoal” zawierający głównie węgiel drzewny i popiół ( $w$ tym pewne ilości ditlenku węgla i wody). Bioolej, po procesie zgazowania i syntezy F-T, stanowi mieszaninę komponentów FT-diesla.

Paliwo HTU-diesel otrzymywane może być z odpadowych substancji organicznych, drzewnych z dużą zawartością wody, tłuszczów i olejów w procesie depolimeryzacji surowców. Produkty procesów rozkładu poddawane są odtlenianiu w procesie hydrolizy. Stosowanie techniki hydroodtleniania tłuszczów (HDO) pozwala także na otrzymywanie bezpośrednio frakcji węglowodorowych komponentów paliwowych z olejów roślinnych z pominięciem zbędnego balastu, jakim jest gliceryna pochodząca z procesów transestryfikacji tych olejów.

Zgazowanie i piroliza biomasy może być także źródłem otrzymywania wodoru, jednak tak otrzymany wodór nie stanowi jeszcze w pełni biopaliwa trzeciej generacji.

Ze względu na zaostrzające się wymagania z zakresu czystości procesów spalania oraz dostępności surowców, prowadzące są prace nad otrzymywaniem paliw do silników spalinowych i urządzeń grzewczych z procesów zgazowania i upłynniania węgla. Procesy prowadzące do ich otrzymywania, $z$ wykorzystaniem metody Fischer-Tropscha oznaczane są jako procesy GtL („gas to liquid”) i CtL (,coal to liquid”).

\section{Normalizacja biopaliw}

Procedury normalizacji biopaliw mają za zadanie określić wymagania jakościowe tych paliw wraz z określeniem metod oceny tych wymagań pod kątem zapewnienia odpowiedniej jakości w procesie eksploatacji (procesach silnikowych), transportu, magazynowania i dystrybucji. W krajach Unii Europejskiej za normalizację odpowiedzialny jest Europejski Komitet Normalizacyjny (CEN), który wydaje normy europejskie EN. Normy te są obowiązujące w państwach Wspólnoty, przy czym są one publikowane wylącznie jako normy krajowe poszczególnych krajów, których komitety normalizacyjne są członkami lub kandydatami na członków CEN, jako normy np.: PN-EN, w Polsce, DIN-EN w Niemczech, BS-EN w Wielkiej Brytanii, itp. W analogiczny sposób publikowane są normy światowe opracowane przez ISO (International Standard Organization), działającą na podstawie mandatu ONZ i będącą federacją krajowych jednostek normalizacyjnych.

W zakresie samoistnych biopaliw, aktualnie przez CEN znormalizowane zostały jedynie wymagania na czyste estry metylowe kwasów tłuszczowych (FAME). W pozostałych przypadkach istnieją normy na odpowiednie mieszanki tych es- 
trów z naftowym olejem napędowym. Dla wielu biopaliw opracowane zostały normy na metody badań niektórych właściwości istotnych dla ich eksploatacji w procesach silnikowych.

W zakresie paliw do silników o zapłonie iskrowym istnieje projekt normy PrEN 15376:2006 na etanol jako komponent benzyny silnikowej. Należy pamiętać, że benzyny silnikowe zawierające do $5 \%(\mathrm{v} / \mathrm{v})$ biokomponentów (głównie etanolu) muszą być zgodne z obowiązującą normą na te paliwa, to jest PN-EN 228:2006. W horyzoncie czasowym pięć do dziesięciu lat, przewidziane jest opracowanie przez CEN norm przedmiotowych na benzyny silnikowe zawierające etanol, to jest: E10, E15, E75-85, oraz E95 (liczby za literą „E” - etanol oznaczają jego stężenie $\mathrm{w} \%(\mathrm{v} / \mathrm{v}) \mathrm{w}$ benzynach silnikowych). Na paliwa zawierające metanol CEN przewiduje opracowanie norm do 2020 roku natomiast w USA istnieje już norma ASTM D 5797-96 z 2001 roku na paliwa z zawartością 75-85\%(v/v) metanolu oraz 14-30\%(v/v) węglowodorów lub eterów alkilowych.

W zakresie paliw do silników o zapłonie samoczynnym istnieje norma europejska i polski odpowiednik dla czystych FAME do celów silnikowych PN-EN 14214:2004. Analogicznie jak dla benzyn, oleje napędowe zawierające do 5\%(v/v) FAME muszą spełniać wymogi jakościowe normy na oleje napędowe PN-EN 590:2006. W normach amerykańskich ASTM, normalizacją objęto estry alkilowe wyższych kwasów thuszczowych (FAME i FAEE) normą ASTM D 6751-03 oraz komponenty tych estrów $\mathrm{z}$ olejem napędowym. Na oleje napędowe zawierające FAME jako komponent, w Polsce istnieje norma zakładowa ZN-05/MGiPS/CN15, na paliwo B20 (Biodiesel o zawartości 20\%(v/v) FAME). Państwowe normy na olej napędowy z dodatkiem 30\%(v/v) FAME istnieją w Czechach i we Włoszech. Normalizacja europejska na oleje napędowe zawierające rożne ilości biokomponentów w tym FAEE prawdopodobnie zakończy się w 2015 roku.

W roku 2007 Komisja Europejska wystąpiła do CEN o pilne podjęcie prac nad opracowaniem norm dla szerszego asortymentu biopaliw, $w$ tym takich paliw jak:

- $\quad$ B10 (10\%(v/v) FAME lub FAEE w oleju napędowym;

- E10 (10\%(v/v) etanolu w benzynach silnikowych;

- DME (eter dimetylowy) do silników o zapłonie samoczynnym;

- Biometan (biogaz),

oraz dopuszczenie w EN 590 wprowadzania do 10\%(v/v) FAME lub FAEE.

\section{Bibliografia}

K. Biernat, Prognoza rozwoju paliw, „Studia Ecologiae et Bioethicae” nr 3/2005;

K. Biernat, A. Kulczycki, Prognoza dla Polski, „Nowe Życie Gospodarcze” dodatek specjalny $\mathrm{Z}$ dnia 26 kwietnia 2006;

K. BIERNAT, Kierunki rozwoju układów zasilania i spalania oraz źródeł energii we wspótczesnych silnikach spalinowych, „Przemysł Chemiczny” grudzień 2006; 
K. Biernat, A. Kulczycki, Prognoza rozwoju biopaliw w Polsce, Krajowa Konferencja „Rynek biopaliw w Polsce - szanse i zagrożenia", Warszawa, 26.04.2006.

K. Biernat, Biopaliwa drugiej generacji, Krajowa Konferencja Biopaliw i Biokomponentów, Gdańsk, 18.10.2006.

K. Biernat, J. GŁąB, Analiza wymagań technicznych, normatywnych oraz wytycznych jakościowych produkcji i stosowania biopaliw w Polsce, Krajowa Konferencja „Biopaliwa w Polsce” 28-29.11.2006, Warszawa

K. Biernat, A. Kulczycki, M. Rogulska, Development of Alternative Fuels in Poland Materiały "Expert Workshop on Biofuels Support in Baltic States, Nordic Countries and Poland”, Tallin, Estonia 14.02.2007.

K. Biernat, M. Mielczarska-Rogulska, Implementation and Properties of Biofuels and Biocomponents, Materiały konferencji "European Transport in FP 7”, Warszawa, 1-2. 03. 2007.

K. Maniatis, Biofuels EU policy and recent developments, Materiały drugiego spotkania Mirror Group ETPB, Bruksela, luty 2007.

J. Merkisz, Ekologiczne aspekty stosowania silników spalinowych, Wyd. Politechniki Poznańskiej, Poznań 1994.

J.M. Mackowski, The EU Directives on Fuels Quality: a look beyond year 2000, Mat. II Międzynarodowej Konferencji pt: „Rozwój technologii paliw w świetle Dyrektyw Europejskich i Narodowych Uregulowań Normatywnych", Warszawa 1999.

J. Gronowicz, Ochrona środowiska w transporcie ladowym, Wyd. ITE Radom 2004.

L.J. Sitnik, Ekopaliwa silnikowe. Oficyna Wydawnicza Politechniki Wrocławskiej, Wrocław 2004.

K. Biernat, A. Łuksa, Weglowodory i tluszcze odpadowe jako ciecze opatowe, „Sozologia” nr 1/2003.

W. Górski, Biopaliwa w normach: ISO, EN i PN, „Przemysł Chemiczny” grudzień 2006.

B.E. Kampman, L.C. den Boer, H.J. Croezen, Biofuels under development, Publication CE No 05.4894.11, Netherlands Petroleum Industry Association, Delft, May. 2005.

\begin{abstract}
In this paper clasification and definitions of biofuels for combustion engines, with special focus on UE and U.S demands for fuels is given. Main feedstocks and technologies of biofuel production, also second generation biofuels, are describe. There is also presented current situation in fuels stadarization.
\end{abstract}

